\title{
Pollination mode determines floral scent
}

Gerard Farré-Armengol $^{\mathrm{a}, \mathrm{b}, *}$, Iolanda Filella ${ }^{\mathrm{a}, \mathrm{b}}$, Joan Llusià ${ }^{\mathrm{a}, \mathrm{b}}$ and Josep Peñuelas ${ }^{\mathrm{a}, \mathrm{b}}$

${ }^{a}$ CSIC, Global Ecology Unit CREAF-CEAB-CSIC-UAB, Cerdanyola del Vallès, 08193

Barcelona, Catalonia, Spain

${ }^{\mathrm{b}}$ CREAF, Cerdanyola del Vallès, 08193 Barcelona, Catalonia, Spain

*corresponding author; e-mail: g.farre@creaf.uab.es, phone number: +34 9358129 15, postal

address: CREAF, Edifici C, Campus de Bellaterra (UAB), 08193 Cerdanyola del Vallès

(Barcelona), Spain. 


\begin{abstract}
The main objective of this study is to determine if the pollination vector influences the potential floral emissions of flowering plants. We hypothesized that flowers pollinated by insects would emit significantly higher amounts of volatile organic compounds (VOCs) and would present a higher diversity of these compounds than flowers pollinated by wind. The floral emissions of fifteen entomophilous species and eleven anemophilous species were captured by dynamic headspace sampling under field conditions and analyzed by gas chromatography-mass spectrometry. We searched for differences in the emission profiles between anemophilous and entomophilous flowers by considering the effects of phylogeny in our analysis. The floral emissions from the two groups were significantly different. Entomophilous species presented highly diverse emissions in both magnitude of emission rates and richness of compounds depending on the species, but overall, the flowers from entomophilous species had much higher VOC emission rates and VOC richness, both for terpenes and benzenoid compounds, than those from anemophilous species (two orders of magnitude higher emissions). The data thus confirm that the presence of intensely scented flowers with complex scents is strongly related to biotic pollination.
\end{abstract}

Keywords: entomophily, anemophily, floral emissions, floral scent, VOC richness.

\title{
1 Introduction
}

Anemophilous plants entrust their pollen to the wind, which serves to deliver the pollen to the stigma and fertilize the ovules. Anemophily requires a large investment in the production of male flowers with abundant pollen to ensure the pollination of few female flowers (Friedman and Barrett, 2009). On the other hand, entomophilous plants rely on visiting insects to perform their pollination. These plants have lower investments in male flowers and pollen, 
but they generally have higher investments in the production of rewards and signals for attracting pollinators (Friedman and Barrett, 2009). The most common floral rewards are nectar and pollen (Simpson and Neff, 1981), but some species offer oils and other less common nutritive resources to the pollinators (Bittrich and Amaral, 1997; Capellari et al., 5 2012; Steiner et al., 2011). Floral signals from entomophilous flowers serve to attract the attention of pollinators. These signals can be visual, such as a perianth with brightly-colored pigmentation (Chwil and Weryszko-Chmielewska, 2009), or olfactory, such as the strong scents of flowers (Parachnowitsch et al., 2012). Pollinators can learn the floral odor of species that offer rewards and establish an association between the stimulus and the presence of these rewards (Riffell, 2011). Generalist pollinators use these specific blends of volatiles to find the flowers with the best rewards in the community, while specialist pollinators use them to find their host plants (Burger et al., 2010; Filella et al., 2011).

The reliance of plants on animal pollination has become a major driver of plant speciation and diversification of floral traits (Bronstein et al., 2006; Kay and Sargent, 2009; Whitney and Glover, 2007). Floral scents are considered to have evolved as attractants of pollinators and have diversified extensively with biotic pollination (Schiestl, 2010; Whitehead and Peakall, 2009). Floral bouquets of volatile compounds have been found to be under strong natural selection by pollinators (Parachnowitsch et al., 2012). The ability of plants to emit volatile organic compounds (VOCs) emerged early in the evolution of the plant kingdom (Chen et al., 2011; Fink et al., 2006; Kamenarska et al., 2002). Floral structures may have emitted VOCs before the need to attract pollinators appeared in angiosperms. Floral volatiles perform functions other than attraction, the most important of which is defense, which has the opposite effect on visitors to flowers (Galen et al., 2011; Junker and Blüthgen, 2010; Kessler et al., 2008; Schiestl, 2010). The attractive function of floral VOCs may have effectively 
appeared as a modification of pre-existent VOC emissions, such as defensive terpenes that deter detrimental organisms or emissions that protect plants against stressful environmental conditions (Pellmyr and Thien, 1986). The display of VOCs emitted by plants has coevolved with the sensory system of pollinators resulting in new species-specific floral bouquets

5 directed to attract particular insect species (Farré-Armengol et al., 2013).

The absence of a need for communication with the pollinator in anemophilous plants, leads to our hypothesis: attractive VOCs are less diversified and less abundantly emitted in anemophilous than in entomophilous flowers.

Magalhães et al. (2005) and Wragg \& Johnson (2011), measuring and comparing the emission of volatiles from flowers of diverse species from the same genus or family, found that the presence and abundance of floral volatiles depended mainly on the mode of pollination, i.e. by insects (entomophily) or by wind (anemophily). Raguso et al. (2007) found that emissions from flowers of different species of Oenothera were higher when flowers are pollinated by insects than by self-pollination. Doubleday et al. (2013) demonstrated that floral fragrance is dramatically lower in selfing compared to outcrossing populations of the species Abronia umbellata. Here we largely increase the range of species studied and analyze the floral emissions of several entomophilous and anemophilous Mediterranean species from diverse families to test our hypothesis while considering the effect of the phylogeny and thus to determine if the two modes of pollination have significant quantitative and qualitative differences in floral emissions. We thus aim to determine the importance of the mode of pollination on the amount and display of volatiles emitted by flowers.

\section{Materials and methods}




\subsection{Scent sampling}

Scent samples were captured by dynamic headspace sampling (Stashenko and Martínez, 2008) under field conditions. Flowers or inflorescences were enclosed in an oven bag (Nalophan, $20 \mathrm{~cm} \times 30 \mathrm{~cm}$ ), without separation from the plant. Air filtered through activated carbon was pumped into the bag via a Teflon entrance tube. Another Teflon tube collected the air exiting the bag, with one side of a T-tube connected to an adsorbent tube that collected the VOCs, followed by a flowmeter and a pump. The flux of air into the bag was always higher than the flux through the adsorbent tube to ensure that all the air from which we sampled the VOCs came from the bag. The influx was between 800 and $2000 \mathrm{~mL} \mathrm{~min}^{-1}$, and the flow through the adsorbent tube was between 400 and $800 \mathrm{~mL} \mathrm{~min}^{-1}$. The other side of the T-tube was open to release the excess air that did not pass through the adsorbent tube. Adsorbent tubes were filled with $114.6 \mathrm{mg}$ of Tenax and $236.8 \mathrm{mg}$ of Carbotrap adsorbents. Floral VOC samples were collected for five minutes. Blank samples with empty bags were collected to confirm the presence or absence of contaminating VOCs in the surrounding air and the sampling system. The filter of activated carbon used to clean the air introduced into the sampling bags did not generate air completely free of VOCs, so we collected additional controls to differentiate the environmental VOCs from those emitted by the samples. We also analyzed the air from clean unused tubes to identify possible contaminating compounds from the decomposition of tube adsorbents during thermal desorption or other contaminants from the system (Vercammen et al., 2000). When the sampling of floral scents was completed, flowers of each sample were cut and dried to obtain the dry weights of the emission sources and to calculate the emission rates relative to dry weight.

The samples were collected during 2012 from different locations in central Catalonia. The criteria used to choose the species were basically two. First, we decided to select species 
that belong to different plant families to have a more diverse and representative sample for each pollination mode. Second, we chose species that flowered successively along the year. Five samples and one or more blank controls were collected for each species. Replicates of each species were taken on different individual plants on the same day and location. Sampling was conducted under field conditions on sunny days. Eleven anemophilous species were sampled: Acer negundo L., Alnus glutinosa L., Coriaria myrtifolia L., Corylus avellana L., Fraxinus angustifolia Vahl, Olea europaea L., Pistacia lentiscus L., Populus nigra L., Quercus pubescens Willd., Ulmus minor Mill., and Vitis vinifera L. Fifteen entomophilous species were sampled: Calendula arvensis L., Diplotaxis erucoides DC., Euphorbia characias L., Helichrysum stoechas L., Lepidium draba L., Ligustrum japonicum Thunb Prunus dulcis Mill., Rhamnus alaternus L., Salvia verbenaca L., Sambucus nigra L., Syringa vulgaris L., Thymus vulgaris L., Tilia platyphyllos Scop., Viburnum lantana L., and V. tinus L.

\subsection{Scent analyses}

VOC analyses were performed by gas chromatography-mass spectrometry (Agilent Technologies, GC: 7890A, MS: 5975C inert MSD with Triple-Axis Detector, Palo Alto, CA, USA). The adsorbent tubes were thermally desorbed, and samples were injected into a $30 \mathrm{~m} \mathrm{x}$ $0.25 \mathrm{~mm}$ capillary column with a $0.25 \mu \mathrm{m}$ film thickness (HP-5MS, Agilent Technologies). Helium flow was $1 \mathrm{~mL} \mathrm{~min}{ }^{-1}$. Total run time was $26 \mathrm{~min}$. After sample injection, the initial time was $1 \mathrm{~min}$, and the initial temperature $\left(35^{\circ} \mathrm{C}\right)$ was increased at $15^{\circ} \mathrm{C} \cdot \mathrm{min}^{-1}$ to $150{ }^{\circ} \mathrm{C}$ and maintained for $5 \mathrm{~min}$, then at $50{ }^{\circ} \mathrm{C} \cdot \mathrm{min}^{-1}$ to $250{ }^{\circ} \mathrm{C}$ and maintained for $5 \mathrm{~min}$ and finally at $30{ }^{\circ} \mathrm{C} \cdot \mathrm{min}^{-1}$ to $280{ }^{\circ} \mathrm{C}$ and maintained for $5 \mathrm{~min}$. 
VOCs were identified by comparing the retention times with liquid standards from Fluka (Buchs, Switzerland) injected into clean adsorbent tubes, and the fractionation mass spectra were compared with standard spectra and the Nist05a and wiley7n mass spectra libraries. VOC concentrations were determined from calibration curves. The calibration curves for the common VOCs $\alpha$-pinene, $\beta$-pinene, limonene, $\alpha$-humulene, 3 -hexen-1-ol and dodecane were determined once every seven analyses. VOC calibration curves $(n=4$ different terpene concentrations) were always highly significant $\left(r^{2}>0.99\right)$ for the relationship between signal and VOC emission rates. We calculated the emission rates of VOCs relative to the dry weights of the flowers $\left(\mu \mathrm{g} \cdot \mathrm{gDW}^{-1} \cdot \mathrm{h}^{-1}\right)$, subtracting the emission rates of the blanks from their respective flower samples.

\subsection{Statistical and phylogenetic analyses}

We conducted PERMANOVA analyses of the floral VOC emission rates with R software. PERMANOVA is a permutational multivariate analysis of variance for testing the simultaneous response of multiple variables to one or more factors on the basis of any distance measure using permutation methods (Anderson, 2006). For this purpose we used the function adonis from the package vegan (Oksanen et al., 2013). Since the data on the emission rates and richness of terpenoids, benzenoids and total VOCs did not show normal distribution we used the Kruskal-Wallis non parametric test for the comparison of anemophilous and entomophilous floral emissions.

We constructed a phylogenetic tree and obtained the phylogenetic distances among species with Phylomatic and Phylocom (Webb and Donoghue, 2005; Webb et al., 2008). Briefly, Phylomatic uses a backbone plant megatree based primarily on DNA data from a variety of studies to assemble a phylogenetic tree for the species of interest. Our phylogenetic 
hypothesis was based on the conservative megatree, where unresolved nodes were included as soft polytomies (Webb and Donoghue, 2005). We used the package picante from R software to test for phylogenetic signals in the floral emissions of the species studied. The function phylosignal calculates a statistic of phylogenetic signal (Blomberg's $\mathrm{K}$ ) as well as a $P$-value

5 based on variance of phylogenetically independent contrasts relative to tip shuffling randomization (Blomberg et al., 2003). We used the package ape from $\mathrm{R}$ software to read and plot the phylogenetic tree and PermutMatrix (Caraux and Pinloche 2005) to construct the image map.

\section{Results}

The emission profiles of entomophilous samples were highly diverse (Figs. 1-3), with different magnitudes of VOC emission rates (Figs. 1-3) and different levels of VOC diversity (Figs. 1 and 3, Table 1). The majority of anemophilous species had low or null floral emission rates, compared with entomophilous species (Fig. 3).

When focusing on terpenes, we detected that entomophilous species had higher mean and higher variance in their total terpene emission rates than anemophilous species (194.8 \pm 159.3and 1.1 $0.6 \mu \mathrm{g} . \mathrm{gDW}^{-1} \cdot \mathrm{h}^{-1}$, respectively; Kruskal-Wallis test, $\left.\chi^{2}=6.8, P=0.009\right)$ and higher mean terpene richness $\left(5.6 \pm 1.1\right.$ and $2.3 \pm 0.8$ compounds, respectively; $\chi^{2}=3.57$, $P=0.06)$ (Fig. 1). Total terpene emission rates showed phylogenetic signal $(\mathrm{K}=0.68, P=0.05$, Table 2).

With respect to benzenoids, our results show that entomophilous species had higher mean and higher variance in their total benzenoid emission rates than anemophilous species $\left(50.6 \pm 41\right.$ and $0.3 \pm 0.1 \mu \mathrm{g} \cdot \mathrm{gDW}^{-1} \cdot \mathrm{h}^{-1}$, respectively; Kruskal-Wallis test, $\left.\chi^{2}=4.1, P=0.04\right)$ and 
higher mean benzenoid richness $\left(1.4 \pm 0.4\right.$ and $0.5 \pm 0.2$ compounds, respectively; $\chi^{2}=2.93$, $P=0.09$ ) (Fig. 1). Total benzenoid emission rates showed phylogenetic signal that was close to significance $(\mathrm{K}=0.68, P=0.07$, Table 2$)$.

Entomophilous species had higher mean and higher variance in their total VOC

5 emission rates than anemophilous species $\left(280.5 \pm 213.8\right.$ and $5.3 \pm 1.9 \mu \mathrm{g} \cdot \mathrm{gDW}^{-1} \cdot \mathrm{h}^{-1}$, respectively; Kruskal-Wallis test, $\chi^{2}=3.5, P=0.06$ ) and also a not significant higher VOC richness $\left(10.7 \pm 2.2\right.$ and $7.6 \pm 1.7$ compounds, respectively; $\left.\chi^{2}=0.39, P=0.53\right)$ (Fig. 1$)$. The PERMANOVA analyses using all single compound emission rates showed that the floral emission rates of anemophilous and entomophilous species differed significantly (pseudo$\mathrm{F}=3.11, P=0.02)$. The phylogenetic signal of total VOC emission rates was close to significance $(\mathrm{K}=0.69, P=0.06$, Table 2$)$.

\section{Discussion}

Our results indicate that anemophilous and entomophilous flowers have different VOC emissions. Entomophilous flowers showed considerably higher, two orders of magnitude, VOC emission rates than did anemophilous flowers (Figs 1-3). The emissions of entomophilous flowers were composed of a higher diversity of compounds, especially terpenes (Fig. 1). These results support our hypothesis that plants with biotic pollination have usually higher emission rates and more complex scents than do plants with abiotic pollination, although this does not always occur, which leads to the high variability presented by entomophilous species.

High emission rates were measured for S. verbenaca and T. vulgaris, two species that belong to the Lamiaceae, a family rich in aromatic species with abundant glandular cells in 
their vegetative and floral tissues (Ascensão et al., 1999). Another species without specialized VOC storage structures, such as $C$. arvensis of the family Asteraceae, also had high floral emission rates and a high diversity of compounds. Some entomophilous flowers, such as those of $V$. tinus and T. platiphyllos, had low emission rates per mass of flower. The high

5 variability in the emission rates presented by entomophilous species can result from differences in the relative reliance on visual and olfactory cues among the different species. Some species may rely more on visual cues to attract pollinators and emit lower amounts of floral VOCs, while others emit strong floral scents. The level of reliance that flowers present on olfactory and other sensory channels may depend on the sensory abilities of the pollinators that they attract (Chittka and Raine, 2006; Fink et al., 2006; Schaefer et al., 2004). For example, Petunia axillaris and $P$. exserta, two closely related species with different pollination syndromes, show divergent reliability on visual and olfactive cues to attract their respective pollinators. The former, which attracts nocturnal moths, has colorless flowers that emit strong scents composed of benzenoids, while the latter attracts hummingbirds with red non-scented flowers (Klahre et al., 2011). Species from the genus Clarkia present non-scented flowers that are pollinated by bees, while one species, $C$. breweri, have evolved a strong floral scent composed of monoterpenes and benzenoids that attract moths to their flowers (Dudareva et al., 1996).

Entomophilous species also presented a high diversity of floral volatile compounds (Fig. 3). Plants with a specialist pollination system may emit floral chemical messages directed to their particular range of pollinators. This can be achieved by using uncommon VOCs that are not present in the floral blends of other species as well as by emitting complex floral blends with unique combinations and proportions of more ubiquitous VOCs (FarréArmengol et al., 2013; Raguso, 2008). The need of species with specialist pollination to 
produce a unique floral scent can therefore stimulate the chemical richness of their floral VOC emissions. On the other side, some flowers visited by generalist pollinators may be able to use simpler blends composed of general attractants, such as the common floral monoterpene $\beta$-ocimene (Filella et al., 2013; Knudsen et al., 2006). has been described to depend on the reliance on different pollinator groups with different olfactory preferences (Dobson, 2006). For example, L. japonicum, S. vulgaris and V. lantana are visited by butterflies (field observations), and their floral scents are mainly composed of benzenoids, $\beta$-ocimene, linalool and lilac aldehydes (Table 1). The ubiquity of bezenoids and the monoterpene linalool in the floral scent of plants pollinated by butterflies and moths has suggested that these compounds are used as attractants of Lepidoptera (Andersson et al., 2002; Dötterl et al., 2006). The common monoterpene (E)- $\beta$-ocimene has been found to elicit strong antennal responses in the butterfly Heliconius melpomene (Andersson and Dobson, 2003) and lilac aldehydes are common in some nectar plants and elicit antennal responses in butterflies and moths (Andersson, 2003; Dötterl et al., 2006). The use of particular VOCs as attractants of a specific kind of pollinator by taking advantage of the innate olfactory preferences shared by insects of the same group may not stimulate higher floral VOC richness within species but may stimulate the differentiation of the floral scent composition among entomophilous species with different pollination syndromes.

Some entomophilous species such as $C$. arvensis, D. erucoides, $T$. vulgaris and $S$. verbenaca are self-compatible and can naturally experience different degrees of selfpollination (Heyn, 1988; Navarro, 1997; Sans and Bonet, 1993; Thompson and Tarayre, 2000), which does not involve the need to provide chemical cues to attract pollinators. However, the self-compatible entomophilous species of this study showed the strongest and 
most diversified floral scents, thus highlighting the importance of maintaining certain levels of crossed pollination even in self-compatible entomophilous species, which can partially rely on self-pollination when biotic pollination vectors are scarce.

Our results demonstrate that the mode of pollination is a crucial factor determining the display

5 of floral VOCs in flowering plants. We conclude that anemophilous species overall present less diversity and lower amounts of floral VOCs than do entomophilous species and that floral scents are though highly variable among entomophilous species. We argue that this variability can be the result of differences in the pollinators to which flowers direct their signals, what can involve different levels of reliance on olfactory signals against other sensory channels.

We thus conclude that the reliance on biotic agents for pollination is a major factor determining the selection for the appearance and significance of floral VOC emissions and of the expression of their synthesis and emission in floral tissues.

\section{Acknowledgements}

This work is supported by the Spanish Government grant CGL2013-48074-P, the Catalan Government grant SGR2014-274, and the European Research Council grant ERC-SyG-

\section{IMBALANCE-P.}




\section{REFERENCES}

Anderson, M.J., 2006. A new method for non-parametric multivariate analysis of variance. Austral Ecol. 26, 32-46.

Andersson, S., 2003. Antennal responses to floral scents in the butterflies Inachis io, Aglais urticae (Nymphalidae), and Gonepteryx rhamni (Pieridae). Chemoecology 13, 13-20. doi:10.1007/s000490300001

Andersson, S., Dobson, H.E.M., 2003. Antennal Responses to Floral Scents in the Butterfly Heliconius melpomene. J. Chem. Ecol. 29, 2319-2330. doi:10.1023/A:1026278531806

Andersson, S., Nilsson, L.A.A., Groth, I., Bergstrom, G., 2002. Floral scents in butterflypollinated plants: possible convergence in chemical composition. Bot. J. Linn. Soc. 140, 129-153. doi:10.1046/j.1095-8339.2002.00068.x 
Ascensão, L., Mota, L., Castro, M.D.M., 1999. Glandular Trichomes on the Leaves and Flowers of Plectranthus ornatus: Morphology, Distribution and Histochemistry. Ann. Bot. 84, 437-447. doi:10.1006/anbo.1999.0937

Bittrich, V., Amaral, M.C.E., 1997. Floral Biology of Some Clusia Species from Central Amazonia. Kew Bull. 52, 617. doi:10.2307/4110290

Blomberg, S.P., Garland, T., Ives, A.R., 2003. Testing for phylogenetic signal in comparative data: behavioral traits are more labile. Evolution 57, 717-45.

Bronstein, J.L., Alarcón, R., Geber, M., 2006. The evolution of plant-insect mutualisms. New Phytol. 172, 412-428. doi:10.1111/j.1469-8137.2006.01864.x

Burger, H., Dötterl, S., Ayasse, M., 2010. Host-plant finding and recognition by visual and olfactory floral cues in an oligolectic bee. Funct. Ecol. 24, 1234-1240. doi:10.1111/j.1365-2435.2010.01744.x

Capellari, S.C., Melo, G.A.R., Aguiar, A.J.C., Neff, J.L., 2012. Floral oil collection by male Tetrapedia bees (Hymenoptera: Apidae: Tetrapediini). Apidologie 43, 39-50.

Chen, F., Tholl, D., Bohlmann, J., Pichersky, E., 2011. The family of terpene synthases in plants: a mid-size family of genes for specialized metabolism that is highly diversified throughout the kingdom. Plant J. 66, 212-229. doi:10.1111/j.1365-313X.2011.04520.x

Chittka, L., Raine, N.E., 2006. Recognition of flowers by pollinators. Curr. Opin. Plant Biol. 9, 428-35. doi:10.1016/j.pbi.2006.05.002

Chwil, M., Weryszko-Chmielewska, E., 2009. The structure of floral elements of Anchusa officinalis L. creating attractants for insects. Acta Agrobot. 62, 37-47.

Dobson, H.E.M., 2006. Relationship between floral fragrance composition and type of pollinator, in: Dudareva, N., Pichersky, E. (Eds.), Biology of Floral Scent. Boca Raton, pp. 147-198.

Dötterl, S., Burkhardt, D., Weissbecker, B., Jürgens, A., Schütz, S., Mosandl, A., 2006. Linalool and lilac aldehyde/alcohol in flower scents. Electrophysiological detection of lilac aldehyde stereoisomers by a moth. J. Chromatogr. A 1113, 231-8. doi:10.1016/j.chroma.2006.02.011

Doubleday, L. a D., Raguso, R. a, Eckert, C.G., 2013. Dramatic vestigialization of floral fragrance across a transition from outcrossing to selfing in Abronia umbellata (Nyctaginaceae). Am. J. Bot. 100, 2280-92. doi:10.3732/ajb.1300159

Dudareva, N., Cseke, L., Blanc, V.M., Pichersky, E., 1996. Evolution of floral scent in Clarkia: novel patterns of S-linalool synthase gene expression in the C. breweri flower. Plant Cell 8, 1137-48. doi:10.1105/tpc.8.7.1137 
Farré-Armengol, G., Filella, I., Llusia, J., Peñuelas, J., 2013. Floral volatile organic compounds: Between attraction and deterrence of visitors under global change. Perspect. Plant Ecol. Evol. Syst. 15, 56-67. doi:10.1016/j.ppees.2012.12.002

Filella, I., Bosch, J., Llusià, J., Peñuelas, A., Peñuelas, J., 2011. Chemical cues involved in the attraction of the oligolectic bee Hoplitis adunca to its host plant Echium vulgare. Biochem. Syst. Ecol. 39, 498-508.

Filella, I., Primante, C., Llusià, J., Martín González, A.M., Seco, R., Farré-Armengol, G., Rodrigo, A., Bosch, J., Peñuelas, J., 2013. Floral advertisement scent in a changing plant-pollinators market. Sci. Rep. 3, 3434. doi:10.1038/srep03434

Fink, P., von Elert, E., Jüttner, F., 2006. Volatile Foraging Kairomones in the Littoral Zone: Attraction of an Herbivorous Freshwater Gastropod to Algal Odors. J. Chem. Ecol. 32, 1867-1881. doi:10.1007/s10886-006-9115-y

Friedman, J., Barrett, S.C.H., 2009. Wind of change: new insights on the ecology and evolution of pollination and mating in wind-pollinated plants. Ann. Bot. 103, 1515-1527. doi:10.1093/aob/mcp035

Galen, C., Kaczorowski, R., Todd, S.L., Geib, J., Raguso, R.A., 2011. Dosage-dependent impacts of a floral volatile compound on pollinators, larcenists, and the potential for floral evolution in the Alpine Skypilot Polemonium viscosum. Am. Nat. 177, 258-272.

Heyn, C.C., 1988. Investing in adaptations to rare events. A reproductive strategy. Lagascalia $15,29-36$.

Junker, R.R., Blüthgen, N., 2010. Floral scents repel facultative flower visitors, but attract obligate ones. Ann. Bot. 105, 777-82. doi:10.1093/aob/mcq045

Kamenarska, Z., Dimitrova-Konaklieva, S., Stefanov, K., Najdenski, H., Tzvetkova, I., Popov, S., 2002. Comparative Study of the Volatile Compounds from Some Black Sea Brown Algae. Bot. Mar. 45, 502-509. doi:10.1515/BOT.2002.053

Kay, K.M., Sargent, R.D., 2009. The Role of Animal Pollination in Plant Speciation: Integrating Ecology, Geography, and Genetics. Annu. Rev. Ecol. Evol. Syst. 40, 637656. doi:10.1146/annurev.ecolsys.110308.120310

Kessler, D., Gase, K., Baldwin, I.T., 2008. Field experiments with transformed plants reveal the sense of floral scents. Science (80-. ). 321, 1200-2. doi:10.1126/science.1160072

Klahre, U., Gurba, A., Hermann, K., Saxenhofer, M., Bossolini, E., Guerin, P.M., Kuhlemeier, C., 2011. Pollinator choice in Petunia depends on two major genetic Loci for floral scent production. Curr. Biol. 21, 730-9. doi:10.1016/j.cub.2011.03.059

Knudsen, J.T., Eriksson, R., Gershenzon, J., Ståhl, B., 2006. Diversity and Distribution of Floral Scent. Bot. Rev. 72, 1-120. 
Magalhães, A.F., Ruiz, A.L.T.G., Flach, A., Faria, A.D., Magalhães, E.G., Amaral, M. do C.E., 2005. Floral scent of Eleocharis elegans (Kunth) Roem. \& Schult. (Cyperaceae). Biochem. Syst. Ecol. 33, 675-679. doi:10.1016/j.bse.2004.12.004

Navarro, L., 1997. Is the dichogamy of Salvia verbenaca (Lamiaceae ) an effective barrier to self-fertilization? Plant Syst. Evol. 207, 111-117.

Oksanen, J., Blanchet, F.G., Kindt, R., Legendre, P., Minchin, P.R., O’hara, R.B., Simpson, G.L., Solymos, P., Stevens, M.H.H., Wagner, H., 2013. vegan: Community Ecology Package.

Parachnowitsch, A.L., Raguso, R.A., Kessler, A., 2012. Phenotypic selection to increase floral scent emission, but not flower size or colour in bee-pollinated Penstemon digitalis. New Phytol. 195, 667-675. doi:10.1111/j.1469-8137.2012.04188.x

Pellmyr, O., Thien, L.B., 1986. Insect Reproduction and Floral Fragrances: Keys to the Evolution of the Angiosperms? Taxon 35, 76. doi:10.2307/1221036

Raguso, R.A., 2008. Wake Up and Smell the Roses: The Ecology and Evolution of Floral Scent. Annu. Rev. Ecol. Evol. Syst. 39, 549-569. doi:10.1146/annurev.ecolsys.38.091206.095601

Raguso, R.A., Kelber, A., Pfaff, M., Levin, R.A., McDade, L.A., 2007. Floral biology of north American Oenothera sect. Lavauxia (Onagraceae): advertisements, rewards, and extreme variation in floral depth. Ann. Missouri Bot. Gard. 94, 236-257. doi:10.3417/0026-6493(2007)94[236:FBONAO]2.0.CO;2

Riffell, J.A., 2011. The Neuroecology of a Pollinator's Buffet: Olfactory Preferences and Learning in Insect Pollinators. Integr. Comp. Biol. 51, 781-793. doi:10.1093/icb/icr094

Sans, F., Bonet, A., 1993. Producción de frutos y semillas en Diplotaxis erucoides (L.) DC. sometida a diferentes tratamientos de polinización. Collect. Bot. 22, 49-54.

Schaefer, H., Schaefer, V., Levey, D., 2004. How plant-animal interactions signal new insights in communication. Trends Ecol. Evol. 19, 577-584.

doi:10.1016/j.tree.2004.08.003

Schiestl, F.P., 2010. The evolution of floral scent and insect chemical communication. Ecol. Lett. 13, 643-656. doi:10.1111/j.1461-0248.2010.01451.x

Simpson, B.B., Neff, J.L., 1981. Floral Rewards: Alternatives to Pollen and Nectar. Ann. Missouri Bot. Gard. 68, 301-322.

Stashenko, E.E., Martínez, J.R., 2008. Sampling flower scent for chromatographic analysis. J. Sep. Sci. 31, 2022-2031. doi:10.1002/jssc.200800151

Steiner, K.E., Kaiser, R., Dötterl, S., 2011. Strong phylogenetic effects on floral scent variation of oil-secreting orchids in South Africa. Am. J. Bot. 98, 1663-1679. doi:10.3732/ajb.1100141 
Thompson, J.D., Tarayre, M., 2000. Exploring the genetic basis and proximate causes of female fertility advantage in gynodioecious Thymus vulgaris. Evolution (N. Y). 54, 1510-1520.

Vercammen, J., Sandra*, P., Baltussen, E., Sandra, T., David, F., 2000. Considerations on Static and Dynamic Sorptive and Adsorptive Sampling to Monitor Volatiles Emitted by Living Plants. J. High Resolut. Chromatogr. 23, 547-553. doi:10.1002/15214168(20000901)23:9<547::AID-JHRC547>3.0.CO;2-7

Webb, C.O., Ackerly, D.D., Kembel, S.W., 2008. Phylocom: software for the analysis of phylogenetic community structure and trait evolution. Bioinformatics 24, 2098-100. doi:10.1093/bioinformatics/btn358

Webb, C.O., Donoghue, M.J., 2005. Phylomatic: tree assembly for applied phylogenetics. Mol. Ecol. Notes 5, 181-183. doi:10.1111/j.1471-8286.2004.00829.x

Whitehead, M.R., Peakall, R., 2009. Integrating floral scent, pollination ecology and population genetics. Funct. Ecol. 23, 863-874. doi:10.1111/j.1365-2435.2009.01620.x

Whitney, H., Glover, B., 2007. Morphology and development of floral features recognised by pollinators. Arthropod. Plant. Interact. 1, 147-158. doi:10.1007/s11829-007-9014-3

Wragg, P.D., Johnson, S.D., 2011. Transition from wind pollination to insect pollination in sedges: experimental evidence and functional traits. New Phytol. 191, 1128-1140. doi:10.1111/j.1469-8137.2011.03762.x 
Table 1. Pollination mode and floral emission rates of single and total VOCs for each species. References supporting the pollination mode of each species are provided: ${ }^{1}$ FernándezRodríguez et al. (2013), ${ }^{2}$ Thompson \& Gornall (1995), ${ }^{3}$ Cuevas \& Polito (2004), ${ }^{4}$ Verdú \& García-Fayos (1998), ${ }^{5}$ Herrera (1987), ${ }^{6}$ Imbert \& Lefèvre (2003), ${ }^{7}$ Fernández-Martínez et al. 5 (2012), ${ }^{8}$ López-almansa et al. (2004), ${ }^{9}$ Di Vecchi-Staraz et al. (2009), ${ }^{10}$ Orueta (2002), ${ }^{11}$ Kunin (1992), ${ }^{12}$ Blancafort \& Gómez (2005), ${ }^{13}$ Scurfield (1962), ${ }^{14}$ Honda et al. (1998), ${ }^{15}$ Gradziel (2009), ${ }^{16}$ Aronne \& Wilcock (1995), ${ }^{17}$ Navarro (1997), ${ }^{18}$ Atkinson \& Atkinson (2002), ${ }^{19}$ Denisow \& Strzałkowska-Abramek (2014), ${ }^{20}$ Matesanz et al. (2911), ${ }^{21}$ Hesse (1993), ${ }^{22}$ Kollmann \& Grubb (2002), ${ }^{23}$ Nebot \& Mateu (1990). Asterisks ${ }^{(*)}$ indicate field observations of flower-visiting insects conducting visits to these species.

\begin{tabular}{|c|c|c|c|}
\hline & $\begin{array}{l}\text { Pollination } \\
\text { mode }\end{array}$ & Floral emission rates $\left(\mu \mathrm{g} \mathrm{g} \mathrm{DW}^{-1} \mathrm{~h}^{-1}\right)$ of single VOCs & $\begin{array}{l}\text { Total floral VOC } \\
\text { emission rates }\end{array}$ \\
\hline $\begin{array}{l}\text { Acer } \\
\text { negundo }\end{array}$ & Anemophily $^{1}$ & $\begin{array}{l}\text { (E)- } \beta \text {-ocimene }(0.057 \pm 0.03),(Z) \text {-3-hexen-1-ol }(12 \pm 7.7) \text {, } \\
\text { tetradecane }(1.1 \pm 1.01) \text {, dodecanoic acid }(0.16 \pm 0.05) \text {, } \\
\text { hexadecane }(1.13 \pm 0.94) \text {, tetradecanoic acid }(1.20 \pm 0.23) \text {, } \\
\text { pentadecanoic acid }(0.54 \pm 0.13) \text {, n-hexadecanoic acid } \\
(3.19 \pm 0.95)\end{array}$ & $19.4 \pm 10.4$ \\
\hline $\begin{array}{l}\text { Alnus } \\
\text { glutinosa }\end{array}$ & Anemophily $^{1}$ & $\begin{array}{l}\text { 3-carene }(0.036 \pm 0.024), 1 R \text { - } \alpha \text {-pinene }(0.18 \pm 0.13),(E)-\beta \text { - } \\
\text { ocimene }(0.023 \pm 0.013) \text {, D-limonene }(0.6 \pm 0.54) \text {, } \\
\text { camphene }(0.041 \pm 0.031), \beta \text {-phellandrene } \\
(0.002 \pm 0.002) \text {, benzenecarboxylic acid }(0.98 \pm 0.24) \text {, } \\
\text { dodecane }(0.37 \pm 0.16) \text {, decanal }(0.31 \pm 0.13) \text {, nonanoic } \\
\text { acid }(0.58 \pm 0.23) \text {, tridecane }(0.068 \pm 0.029) \text {, tetradecane } \\
(0.34 \pm 0.13), \text { pentadecane }(0.42 \pm 0.19), \text { hexadecane } \\
(0.37 \pm 0.2)\end{array}$ & $4.3 \pm 1.6$ \\
\hline
\end{tabular}




\begin{tabular}{|c|c|c|c|}
\hline $\begin{array}{l}\text { Coriaria } \\
\text { myrtifolia }\end{array}$ & Anemophily $^{2}$ & $\begin{array}{l}\text { ethylbenzene }(0.28 \pm 0.1) \text {, p-xylene }(1.07 \pm 0.43) \text {, o-xylene } \\
(0.57 \pm 0.25) \text {, decane }(0.23 \pm 0.13), 1,3,5 \text {-trimethyl- } \\
\text { benzene }(0.5 \pm 0.3) \text {, undecane }(0.26 \pm 0.19) \text {, nonanal } \\
(0.61 \pm 0.38) \text {, dodecane }(0.4 \pm 0.22) \text {, decanal }(0.63 \pm 0.35) \text {, } \\
\text { tetradecane }(0.54 \pm 0.32) \text {, tetradecanoic acid }(1.01 \pm 0.21) \text {, } \\
\text { pentadecanoic acid }(0.64 \pm 0.15), n-\text { hexadecanoic acid } \\
(4.2 \pm 0.95) \text {, octadecanoic acid }(0.6 \pm 0.22)\end{array}$ & $11.5 \pm 3.2$ \\
\hline $\begin{array}{l}\text { Corylus } \\
\text { avellana }\end{array}$ & Anemophily $^{1}$ & $\begin{array}{l}\text { 3-carene }(0.014 \pm 0.01), 1 R \text { - } \alpha \text {-pinene }(1.05 \pm 1.03) \text {, } \\
\text { camphene }(0.12 \pm 0.07) \text {, benzenecarboxylic acid } \\
(0.88 \pm 0.65) \text {, hexanal }(0.18 \pm 0.11) \text {, heptanal }(0.23 \pm 0.08) \text {, } \\
\text { nonanoic acid }(0.76 \pm 0.41) \text {, n-decanoic acid }(0.412559) \text {, } \\
\text { tetradecane }(0.71 \pm 0.63) \text {, dodecanoic acid }(0.068 \pm 0.031)\end{array}$ & $4.4 \pm 2.3$ \\
\hline $\begin{array}{l}\text { Fraxinus } \\
\text { angustifolia }\end{array}$ & Anemophily $^{1}$ & $\begin{array}{l}\text { 3-carene }(0.27 \pm 0.17), 1 R \text { - } \alpha \text {-pinene }(2.88 \pm 2.21) \text {, D- } \\
\text { limonene }(2.64 \pm 1.66) \text {, camphene }(0.23 \pm 0.16) \text {, } \\
\text { ethylbenzene }(0.59 \pm 0.48), p \text {-xylene }(1.99 \pm 1.84) \text {, } \\
\text { benzenecarboxylic acid }(0.26 \pm 0.08) \text {, nonanal } \\
(0.38 \pm 0.32) \text {, dodecanoic acid }(0.49 \pm 0.14) \text {, tetradecanoic } \\
\text { acid }(0.24 \pm 0.12) \text {, pentadecanoic acid }(0.21 \pm 0.08), n \text { - } \\
\text { hexadecanoic acid }(0.72 \pm 0.4) \text {, eicosane }(0.08 \pm 0.04)\end{array}$ & $11.0 \pm 7.1$ \\
\hline $\begin{array}{l}\text { Olea } \\
\text { europaea }\end{array}$ & Anemophily $^{3}$ & $\begin{array}{l}\text { tetradecane }(0.76 \pm 0.64), \text { pentadecanoic acid } \\
(0.14 \pm 0.12), n \text {-hexadecanoic acid }(0.86 \pm 0.75)\end{array}$ & $1.8 \pm 1.5$ \\
\hline $\begin{array}{l}\text { Pistacia } \\
\text { lentiscus }\end{array}$ & Anemophily ${ }^{4,5}$ & $\begin{array}{l}\text { 3-carene }(0.13 \pm 0.04), 1 R \text { - } \alpha \text {-pinene }(0.47 \pm 0.28), \beta \text {-pinene } \\
(0.12 \pm 0.07),(E) \text { - } \beta \text {-ocimene }(0.12 \pm 0.05), D \text {-limonene } \\
(0.32 \pm 0.23), \alpha \text {-phellandrene }(0.74 \pm 0.49), \beta \text {-phellandrene } \\
(0.33 \pm 0.24) \text {, dodecanoic acid }(0.16 \pm 0.08) \text {, } \\
\text { pentadecanoic acid }(0.06 \pm 0.04), n \text {-hexadecanoic acid }\end{array}$ & $3.2 \pm 1.5$ \\
\hline
\end{tabular}




\begin{tabular}{|c|c|c|c|}
\hline & & $\begin{array}{l}(0.52 \pm 0.27), \text { E-9-octadecenoic acid }(0.09 \pm 0.047) \text {, } \\
\text { octadecanoic acid }(0.19 \pm 0.09)\end{array}$ & \\
\hline $\begin{array}{l}\text { Populus } \\
\text { nigra }\end{array}$ & Anemophily $^{6}$ & not detected & not detected \\
\hline $\begin{array}{l}\text { Quercus } \\
\text { pubescens }\end{array}$ & Anemophily $^{7}$ & not detected & not detected \\
\hline $\begin{array}{l}\text { Ulmus } \\
\text { minor }\end{array}$ & Anemophily $^{8}$ & $\begin{array}{l}\text { 3-carene }(0.24 \pm 0.21), 1 R-\alpha \text {-pinene }(1.34 \pm 0.74) \text {, D- } \\
\text { limonene }(0.28 \pm 0.25) \text {, camphene }(0.11 \pm 0.06) \text {, decane } \\
(0.047 \pm 0.019), 1,2,3 \text {-trimethyl-benzene }(0.066 \pm 0.046) \text {, } \\
\text { undecane }(0.091 \pm 0.014) \text {, decanal }(0.068 \pm 0.038) \text {, } \\
\text { hexadecane }(0.064 \pm 0.042) \text {, octadecane }(0.027 \pm 0.018)\end{array}$ & $2.3 \pm 0.9$ \\
\hline Vitis vinifera & Anemophily $^{9}$ & not detected & not detected \\
\hline $\begin{array}{l}\text { Calendula } \\
\text { arvensis }\end{array}$ & Entomophily $^{10}$ & 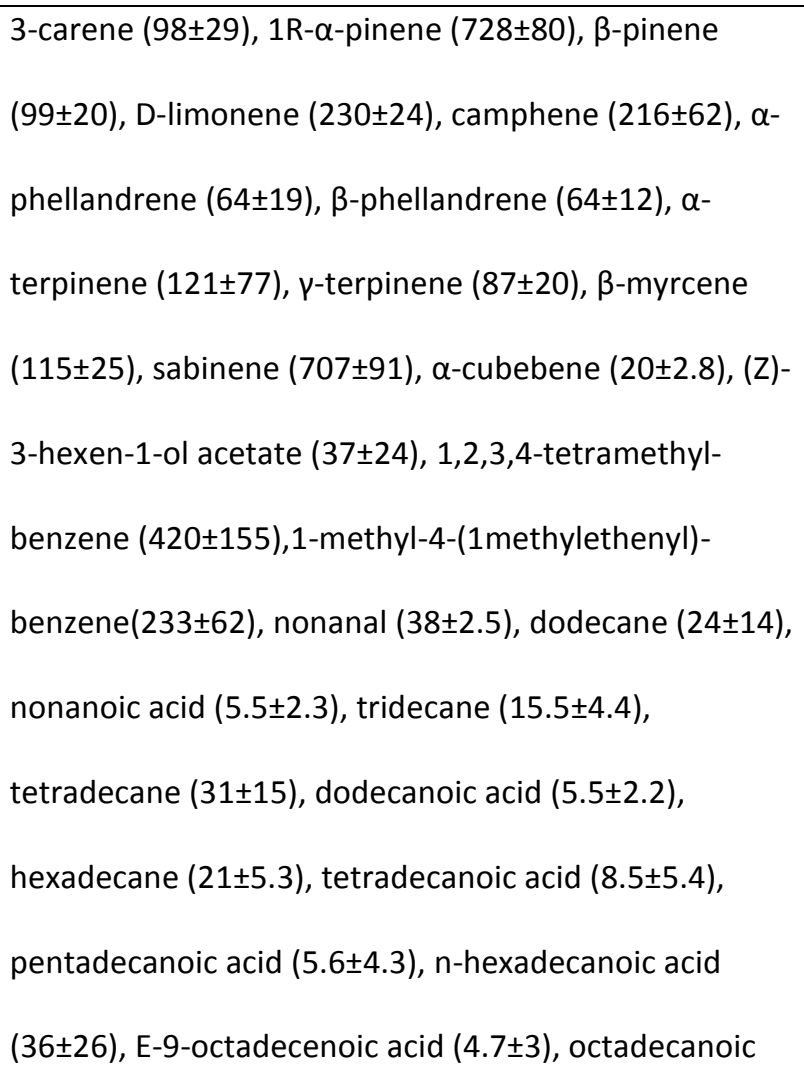 & $3447.9 \pm 553.4$ \\
\hline
\end{tabular}




\begin{tabular}{|c|c|c|c|}
\hline & & acid $(13 \pm 7.4)$ & \\
\hline $\begin{array}{l}\text { Diplotaxis } \\
\text { erucoides }\end{array}$ & Entomophily $^{11, *}$ & 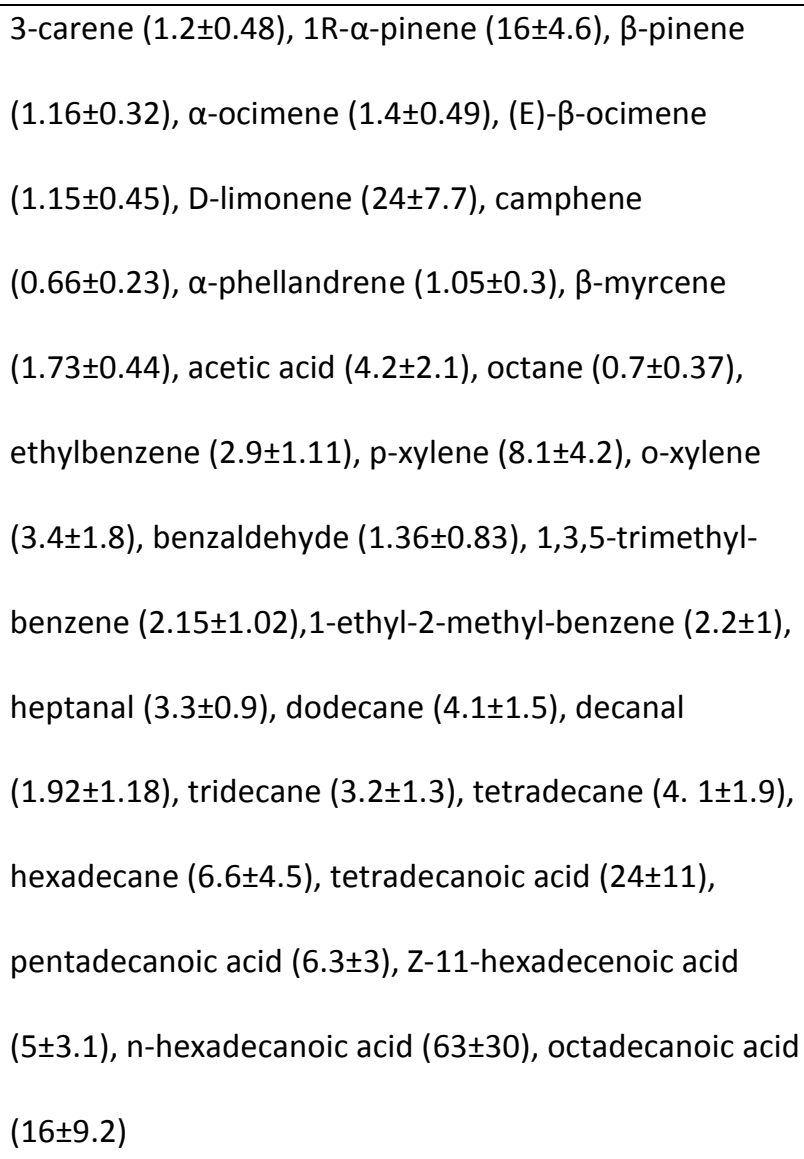 & $210.8 \pm 55.3$ \\
\hline $\begin{array}{l}\text { Euphorbia } \\
\text { characias }\end{array}$ & Entomophily $^{12}$ & $\begin{array}{l}\text { camphene }(0.42 \pm 0.42), \beta \text {-phellandrene }(0.66 \pm 0.61) \text {, } \\
\text { benzaldehyde }(3.4 \pm 2.9) \text {, hexanal }(0.73 \pm 0.31) \text {, } \\
\text { octadecanoic acid }(1.47 \pm 0.25)\end{array}$ & $6.7 \pm 3.6$ \\
\hline $\begin{array}{l}\text { Helichrysum } \\
\text { stoechas }\end{array}$ & Entomophily $^{5, *}$ & $\begin{array}{l}\text { 1R- } \alpha \text {-pinene }(14.3 \pm 2.8), 1 S \text { - } \alpha \text {-pinene }(0.56 \pm 0.13) \text {, } \\
\text { camphene }(1.78 \pm 0.4)\end{array}$ & $16.6 \pm 3.1$ \\
\hline $\begin{array}{l}\text { Lepidium } \\
\text { draba }\end{array}$ & Entomophily $^{13, *}$ & $\begin{array}{l}\text { 1R- } \alpha \text {-pinene }(0.028 \pm 0.012),(E)-\beta \text {-ocimene } \\
(0.033 \pm 0.014) \text {, D-limonene }(0.18 \pm 0.05), \gamma \text {-terpinene } \\
(0.039 \pm 0.014) \text {, benzaldehyde }(0.18 \pm 0.04) \text {, } \\
\text { benzenecarboxylic acid }(0.72 \pm 0.08) \text {, undecane } \\
(0.068 \pm 0.018) \text {, dodecane }(0.14 \pm 0.03) \text {, tridecane } \\
(0.17 \pm 0.06) \text {, tetradecane }(0.23 \pm 0.08) \text {, pentadecanoic }\end{array}$ & $7.9 \pm 3.1$ \\
\hline
\end{tabular}




\begin{tabular}{|c|c|c|c|}
\hline & & $\begin{array}{l}\text { acid }(0.37 \pm 0.09), \mathrm{n} \text {-hexadecanoic acid }(3.1 \pm 1.2) \text {, E-9- } \\
\text { octadecenoic acid }(0.69 \pm 0.31) \text {, octadecanoic acid } \\
(1.88 \pm 1.32)\end{array}$ & \\
\hline $\begin{array}{l}\text { Ligustrum } \\
\text { japonicum }\end{array}$ & Entomophily $^{14, *}$ & 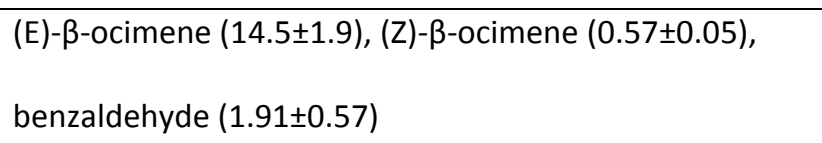 & $17.0 \pm 2.5$ \\
\hline $\begin{array}{l}\text { Prunus } \\
\text { dulcis }\end{array}$ & Entomophily $^{15, *}$ & $\begin{array}{l}\text { 1R- } \alpha \text {-pinene }(8.7 \pm 5.1), \beta \text {-pinene }(0.43 \pm 0.25),(E)-\beta \text { - } \\
\text { ocimene }(1 \pm 0.17), D \text {-limonene }(5.7 \pm 4.3), \text { camphene } \\
(0.23 \pm 0.23), \alpha \text {-phellandrene }(0.6 \pm 0.4), \beta \text {-phellandrene } \\
(0.25 \pm 0.11), \beta \text {-myrcene }(0.54 \pm 0.3)\end{array}$ & $17.4 \pm 10.5$ \\
\hline $\begin{array}{l}\text { Rhamnus } \\
\text { alaternus }\end{array}$ & Entomophily $^{16, *}$ & $\begin{array}{l}\text { 3-carene }(0.66 \pm 0.37), 1,2,3 \text {-trimethyl-benzene } \\
(0.26 \pm 0.13) \text {, tetradecane }(1.07 \pm 0.84)\end{array}$ & $2.0 \pm 1.3$ \\
\hline $\begin{array}{l}\text { Salvia } \\
\text { verbenaca }\end{array}$ & Entomophily $^{17}$ & $\begin{array}{l}\text { 1R- } \alpha \text {-pinene }(1.19 \pm 0.53), \alpha \text {-ocimene }(1.42 \pm 0.35),(E) \text { - } \beta \text { - } \\
\text { ocimene }(2.54 \pm 0.77), D \text {-limonene }(2.27 \pm 0.57), \beta \text { - } \\
\text { phellandrene }(1.23 \pm 0.55), \beta \text {-myrcene }(0.43 \pm 0.31), \alpha \text { - } \\
\text { fenchene }(0.43 \pm 0.09) \text {, lilac aldehyde A }(2.9 \pm 1) \text {, lilac } \\
\text { aldehyde C ( } 2.41 \pm 0.73), p \text {-xylene }(122 \pm 62), 1,2,4 \text { - } \\
\text { trimethyl-benzene }(134 \pm 89)\end{array}$ & $270.9 \pm 123.4$ \\
\hline $\begin{array}{l}\text { Sambucus } \\
\text { nigra }\end{array}$ & Entomophily $^{18, *}$ & $\begin{array}{l}\text { 3-carene }(2.94 \pm 0.79),(E)-\beta \text {-ocimene }(1.27 \pm 0.15) \text {, linalool } \\
\text { oxide }(0.42 \pm 0.08),(Z) \text {-3-hexen-1-ol }(1.15 \pm 0.3) \text {, p-xylene } \\
(0.097 \pm 0.037) \text {, benzenecarboxylic acid }(2.03 \pm 0.72)\end{array}$ & $7.9 \pm 1.6$ \\
\hline $\begin{array}{l}\text { Syringa } \\
\text { vulgaris }\end{array}$ & Entomophily $^{19, *}$ & $\begin{array}{l}\text { 3-carene }(0.3 \pm 0.19), 1 \text { R } \alpha \text {-pinene }(0.32 \pm 0.17), \beta \text {-pinene } \\
(0.098 \pm 0.054),(E) \text { - } \beta \text {-ocimene }(1.01 \pm 0.47),(Z) \text { - } \beta \text {-ocimene } \\
(0.042 \pm 0.021), D \text {-limonene }(0.025 \pm 0.015) \text {, lilac aldehyde } \\
\text { B }(0.84 \pm 0.63) \text {, lilac aldehyde C }(0.6 \pm 0.45), p \text {-xylene } \\
(0.047 \pm 0.019),(\text { methoxymethyl)-benzene }(0.069 \pm 0.031) \text {, }\end{array}$ & $6.5 \pm 3.9$ \\
\hline
\end{tabular}




\begin{tabular}{|c|c|c|c|}
\hline & & $\begin{array}{l}\text { benzeneacetaldehyde }(0.94 \pm 0.43), 1,2,4 \text {-trimethyl- } \\
\text { benzene }(0.023 \pm 0.013) \text {, benzenecarboxylic acid } \\
(0.28 \pm 0.25), 1,4 \text {-dimethoxy-benzene }(1.43 \pm 1.09) \text {, } \\
\text { nonanoic acid }(0.23 \pm 0.17) \text {, dodecanal }(0.0 .38 \pm 0.025) \text {, } \\
\text { pentadecane }(0.031 \pm 0.01) \text {, hexadecane }(0.059 \pm 0.019) \text {, } \\
\text { nonandecane }(0.024 \pm 0.014), 1,2 \text {-benzenedicarboxylic } \\
\text { acid }(0.068 \pm 0.02)\end{array}$ & \\
\hline $\begin{array}{l}\text { Thymus } \\
\text { vulgaris }\end{array}$ & Entomophily $^{20, *}$ & 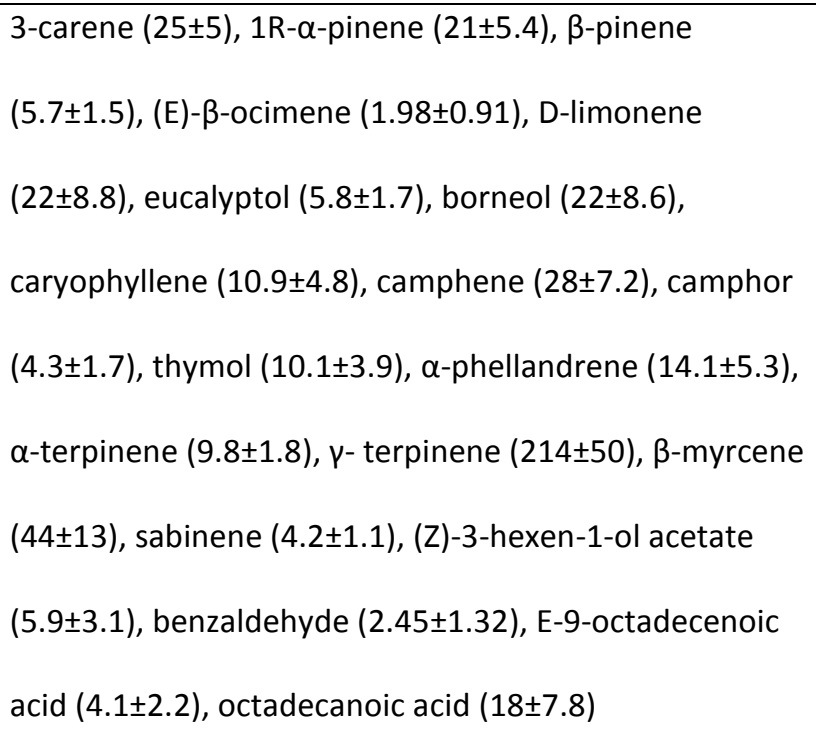 & $472.2 \pm 90.6$ \\
\hline $\begin{array}{l}\text { Tilia } \\
\text { platiphyllos }\end{array}$ & Entomophily $^{21, *}$ & $\begin{array}{l}\text { (E)- } \beta \text {-ocimene }(0.39 \pm 0.05), \alpha \text {-terpinolene }(0.096 \pm 0.012) \text {, } \\
\text { (E)-9-octadecenoic acid }(0.12 \pm 0.08) \text {, octadecanoic acid } \\
(0.17 \pm 0.10)\end{array}$ & $0.8 \pm 0.2$ \\
\hline $\begin{array}{l}\text { Viburnum } \\
\text { lantana }\end{array}$ & Entomophily $^{22, *}$ & $\begin{array}{l}\text { linalool }(1.27 \pm 0.38), \beta \text {-myrcene }(0.21 \pm 0.07) \text {, lilac } \\
\text { aldehyde A }(0.14 \pm 0.02) \text {, lilac aldehyde B }(0.18 \pm 0.02) \text {, } \\
\text { lilac aldehyde D }(0.045 \pm 0.004) \text {, dodecane }(0.04 \pm 0.02) \text {, } \\
\text { tridecane }(0.047 \pm 0.019) \text {, tetradecane }(0.15 \pm 0.08) \text {, } \\
\text { hexadecane }(0.088 \pm 0.042)\end{array}$ & $2.2 \pm 0.4$ \\
\hline Viburnum & Entomophily $^{23}$ & not detected & not detected \\
\hline
\end{tabular}


Table 2. Results of the phylogenetic signal tests for total terpene emission rates, total benzenoid emission rates, total VOC emission rates, terpene richness, benzenoid richness and VOC richness. Bloomberg's $\mathrm{K}$ and $P$-values are provided for each variable.

\begin{tabular}{|l|l|l|}
\hline & \multicolumn{1}{|c|}{$\mathrm{K}$} & \multicolumn{1}{c|}{$P$} \\
\hline Total terpene emission rates & 0.68 & 0.05 \\
\hline Total benzenoid emission rates & 0.68 & 0.07 \\
\hline Total VOC emission rates & 0.69 & 0.06 \\
\hline Terpene richness & 0.54 & 0.14 \\
\hline Benzenoid richness & 0.46 & 0.45 \\
\hline VOC richness & 0.47 & 0.35 \\
\hline
\end{tabular}

5 


\section{Figure captions}

Figure 1. Box plots of $\mathbf{A}$ ) logarithm of total terpene emission rates, B) terpene richness; C)

logarithm of total benzenoid emission rates, D) benzenoid richness; E) logarithm of total VOC emission rates, and $\mathbf{F})$ VOC richness, for anemophilous $(\mathrm{n}=11)$ and entomophilous

$5 \quad(\mathrm{n}=15)$ species. Asterisks indicate the level of significance: ${ }^{(*)}(P<0.1), *(P<0.05), * *$ $(P<0.01)$.
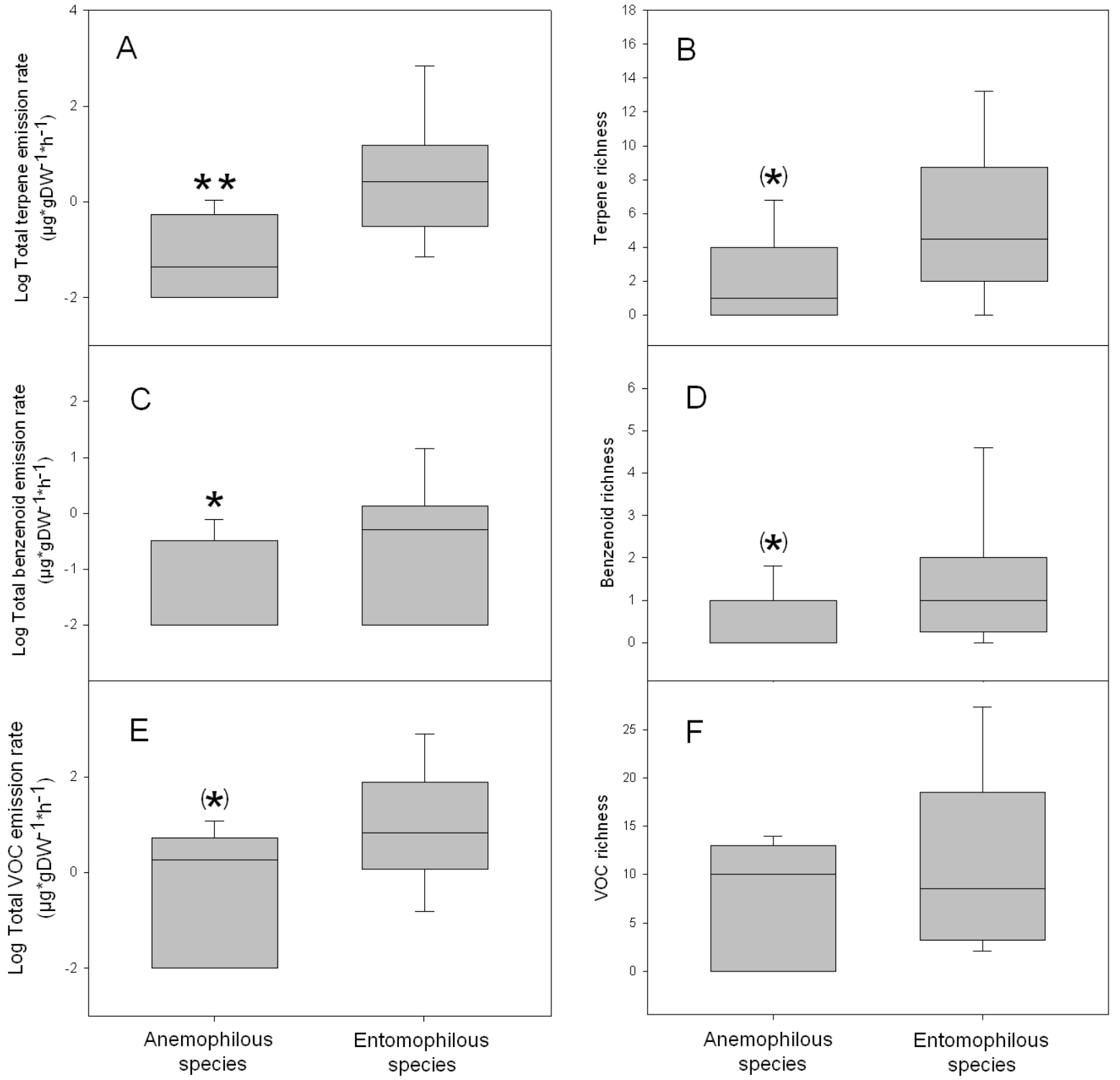
Figure 2. Phylogenetic tree with the phylogenetic distances among the species sampled in this study. The modes of pollination of each species are identified by blue (anemophilous) and red (entomophilous) squares. Total VOC emission rates $\left(\mu \mathrm{g} \mathrm{gDW}^{-1} \mathrm{~h}^{-1}\right)$ are provided for each species.

Total VOC emission rates

( $\left.\mu g \mathrm{~g} \mathrm{DW} \mathrm{W}^{-1} h^{-1}\right)$

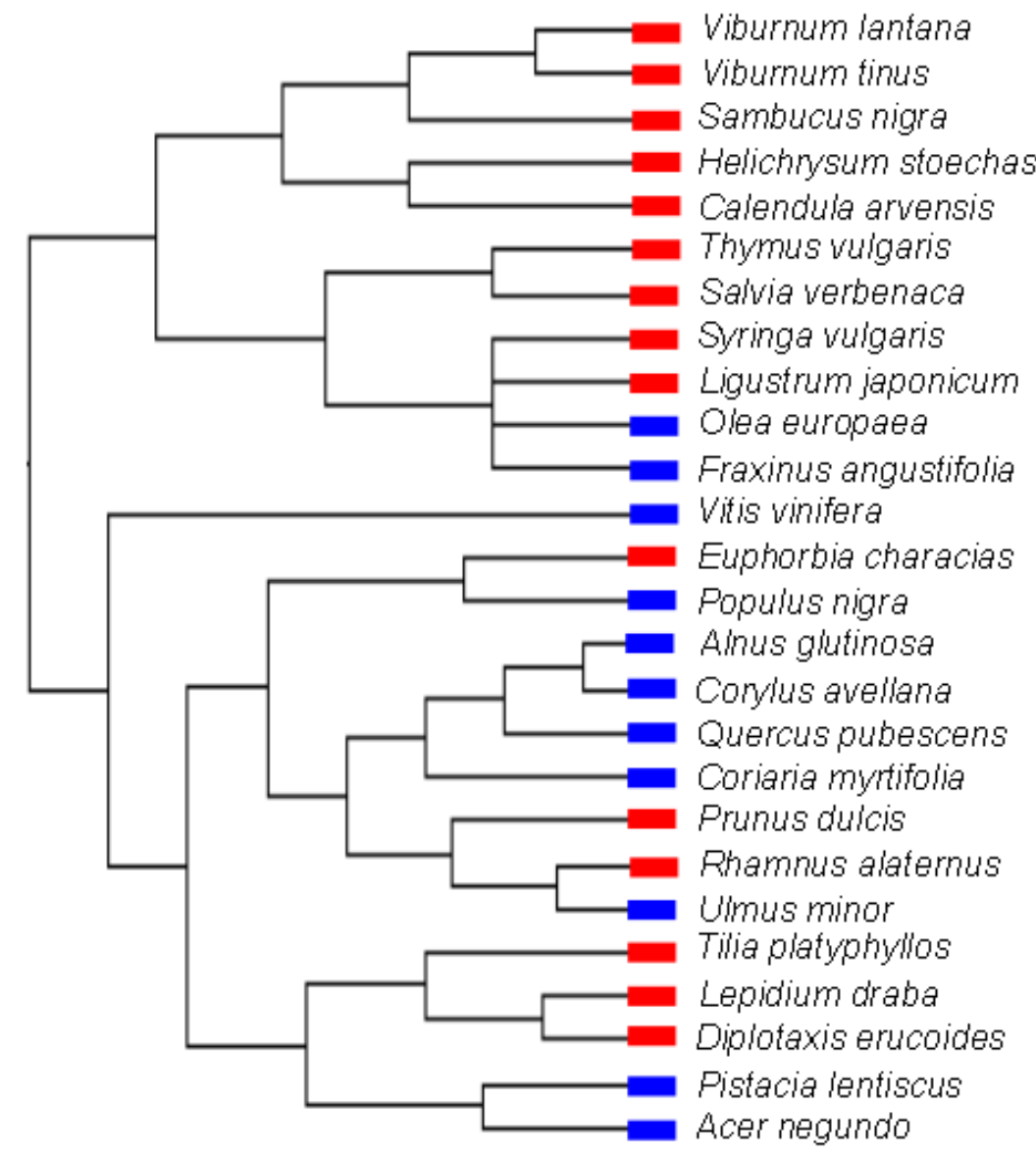

$2.2 \pm 0.4$

n.d.

$7.9 \pm 1.6$

$16.6 \pm 3.1$

$3447.9 \pm 553.4$

$472.2 \pm 90.6$

$270.9 \pm 123.4$

$6.5 \pm 3.9$

$17.0 \pm 2.5$

$1.8 \pm 1.5$

$11.0 \pm 7.1$

n.d.

$6.7 \pm 3.6$

n.d.

4. $3 \pm 1.6$

$4.4 \pm 2.3$

n.d.

$11.5 \pm 3.2$

$17.4 \pm 10.5$

2. $0 \pm 1.3$

$2.3 \pm 0.9$

$0.8 \pm 0.2$

$7.9 \pm 3.1$

$210.8 \pm 55.3$

$3.2 \pm 1.5$

$19.4 \pm 10.4$ 
Figure 3. Image map of terpene and benzenoid emission rates of flowers for anemophilous and entomophilous species. The data are expressed as $\log \left(\mu \mathrm{g} \mathrm{gW}^{-1} \mathrm{~h}^{-1}\right)$.

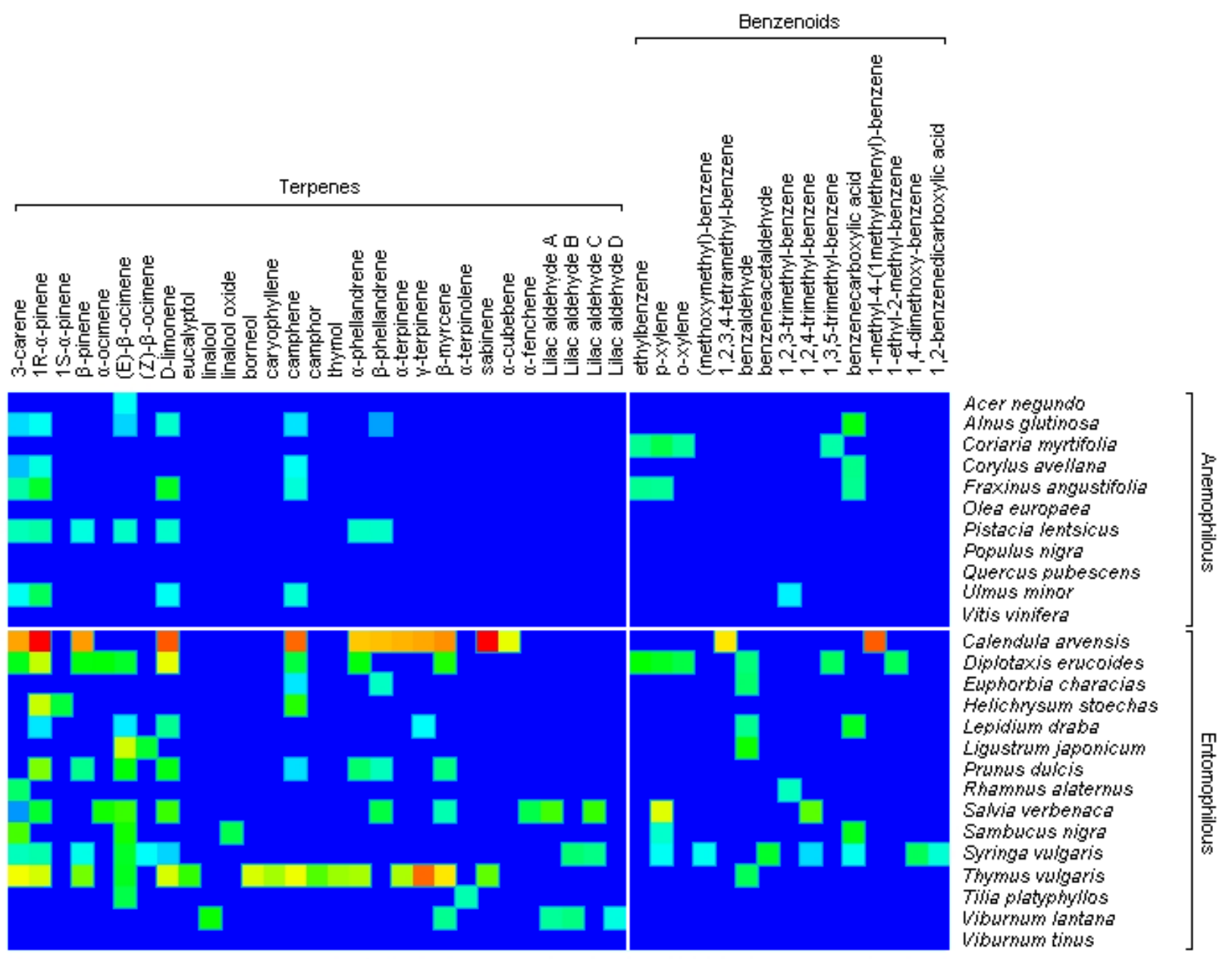

